\title{
A NEW SPECIES OF AQUILARIA (THYMELAEACEAE) FROM VIETNAM
}

\author{
LE CONG KIET ${ }^{1}$, PAUL J. A. KESSLER ${ }^{2} \&$ MARCEL EURLINGS ${ }^{2}$
}

\begin{abstract}
SUMMARY
A new species of Aquilaria is described from Vietnam and keys to the flowering and fruiting specimens of all species from this region are provided. DNA sequences of the nrITS1-5.8S-ITS2 region seem to confirm its status as a distinct species.
\end{abstract}

Key words: Aquilaria, Thymelaeaceae, nrITS, taxonomy, Vietnam.

\section{INTRODUCTION}

During a survey on wild and cultivated Aquilaria populations in the Central Highlands of Vietnam, one interesting Aquilaria was identified in the Sa Thay district, Kontum province. It is similar to other Aquilaria species in almost all vegetative characters, but critical examination of the fruits revealed that it is not only different from the three Aquilaria species so far described from Vietnam, namely A. crassna Pierre ex Lecomte, A. baillonii Pierre ex Lecomte, and A. banaensis P.H. Hô (Hô,1992), but also to the whole genus Aquilaria.

This genus comprises so far 20 species, distributed in tropical and subtropical Asia from Southern China throughout the Malesian region extending to the Pacific Islands (Domke, 1934), with the majority of species in Malesia (Hou, 1960).

To check whether molecular characters would support recognition of the above described specimens as a distinct species, DNA sequences were obtained from the nuclear ribosomal ITS1-5.8S-ITS2 region, which was found to show variation between closely related species of Aquilaria and Gyrinops in a pilot study on molecular identification of cultivated and wild gaharu (Eurlings \& Gravendeel, in press).

\section{MATERIALS AND METHODS}

Total genomic DNA was extracted from $20 \mathrm{mg}$ of silicagel dried leaf material of several different accessions of Aquilaria and Gyrinops (see Table 1) using the DNeasy Plant extraction kit and protocols of QIAGEN (Venlo, The Netherlands). PCR products of the nrITS1-5.8S-ITS2 region were collected using the primers described in White et al.

1) Department of Botany and Ecology, School of Natural Sciences, Vietnam National University, Ho Chi Minh City, Vietnam; e-mail: lecongkiet@yahoo.com.

2) Nationaal Herbarium Nederland, Universiteit Leiden branch, P.O. Box 9514, 2300 RA Leiden, The Netherlands; e-mail corresponding author: Kessler@nhn.leidenuniv.nl. 

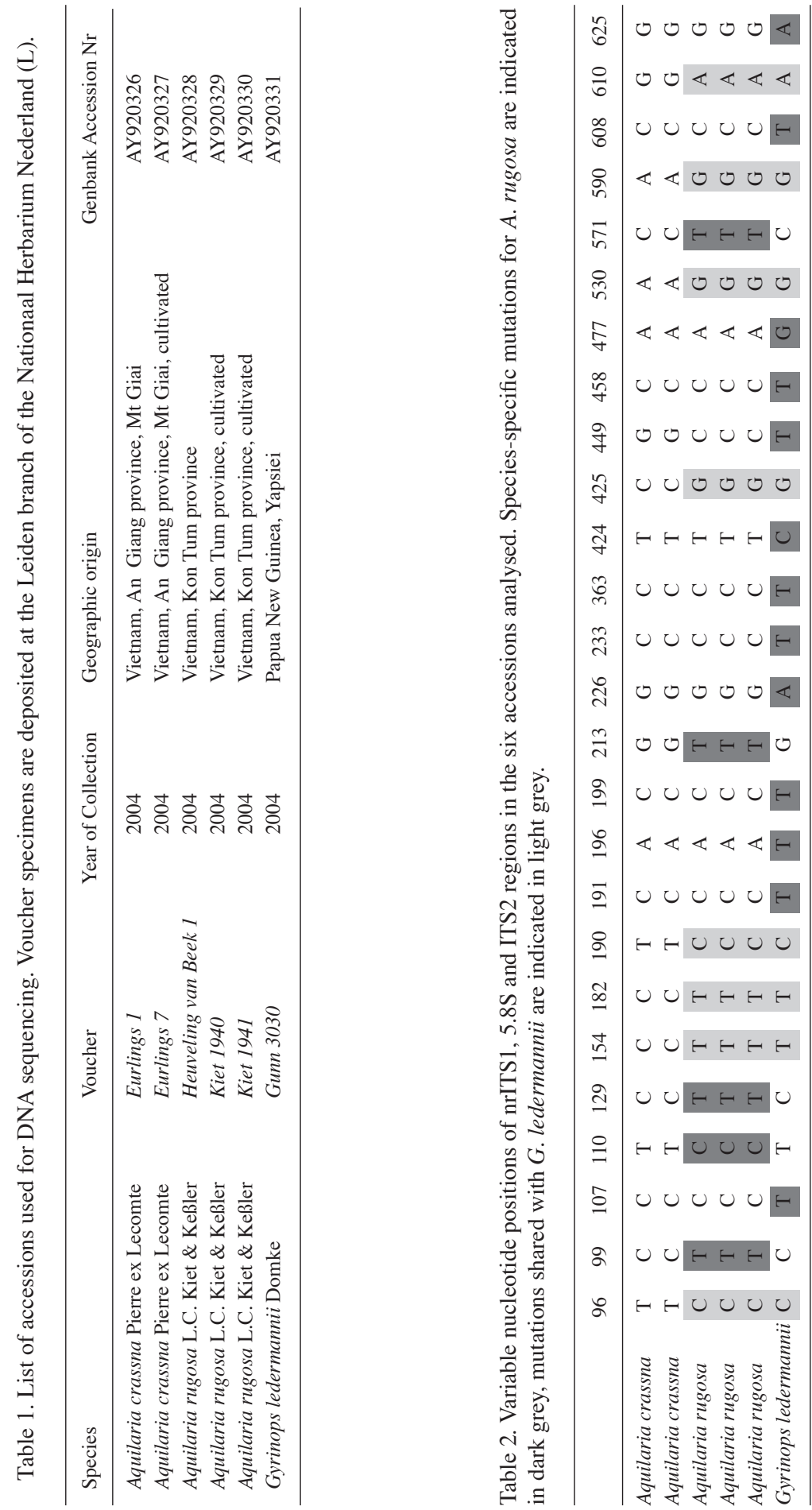
(1990). DNA sequences were obtained on an ABI 377 automated sequencer (Applied Biosystems) using the protocols described in Eurlings \& Gravendeel (in press) and submitted to GenBank under accession numbers AY920326-AY920331.

\section{RESULTS}

The nrITS1-5.8S-ITS2 alignment contained 649 positions of which 26 were variable. Five substitutions were unique to A. rugosa. Pairwise similarity between the latter species and A. crassna and G. ledermannii was $97.8 \%$ and $97.1 \%$, respectively. Pairwise similarity between A. crassna and G. ledermannii was $96.7 \%$. Furthermore, A. rugosa shared 13 mutations with $A$. crassna and eight mutations with $G$. ledermannii (see Table 2).

\section{DISCUSSION}

The molecular results obtained seem to confirm the status of A. rugosa as a separate species, as a total of eight substitutions in the nrITS1-5.8S-ITS2 region were found between this species and the morphologically most similar A. crassna also occurring in Vietnam. It must be stressed, though, that more different accessions of all species of Aquilaria occurring in Vietnam need to be analysed to assess genotypic variability properly.

\section{TAXONOMIC TREATMENT}

Aquilaria Lam. (1783) 49. - Type: Aquilaria malaccensis Lam.

Trees and shrubs. Inner bark without glistening fibres. Leaves alternate, entire; veins \pm parallel; margin thickened, recurved. Inflorescences axillary, supra-axillary, terminal or rarely born on the tree trunk or older branches, sessile or on short peduncles, simple or rarely branched, umbellate or paniculate. Flowers 5-merous, pedicelled, hypanthium (calyx tube or floral tube) cup-shaped, cylindrical or bell-shaped; calyx lobes (4 or) 5 (or 6), erect or recurved, usually shorter than calyx tube; petaloid appendages distinct, twice as many as calyx lobes, hairy, inserted at the base of calyx lobes; stamens 10 , inserted in two whorls, anthers dorsifixed; disk none or rarely ring-like; ovary ovoid to ellipsoid, sessile or stiped, pubescent, 1- or 2-celled, ovule 1 per cell; style obscure or absent; stigma capitate or \pm globose. Fruits loculicidal capsules, ovoid, ellipsoid, oblanceolate or globose, \pm compressed, smooth or rugose; pericarp woody or spongious, dehiscent, valves stretched at acute to obtuse angles; seed(s) 1 or 2, ovoid or ellipsoid, apex acute, acuminate or beaked, base adnate to the caruncle-like or tail-shaped appendage and dangling at the ends of filiform or obscure funicles.

Distribution - About 20 species from India, Burma, Indochina, SE China, and widespread in Southeast Asia. In Vietnam so far 4 species recorded. 


\title{
KEYS TO AQUILARIA SPECIES IN VIETNAM
}

Flowering material (except A. banaensis of which flowers are unknown)

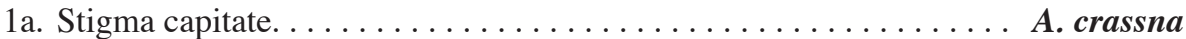

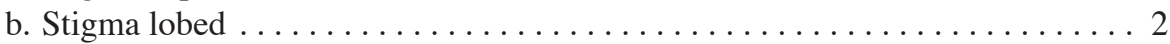

2a. Stigma irregularly lobed, ovary rectangular in cross section . . . . . . A. rugosa

b. Stigma regularly lobed, ovary circular in cross section. . . . . . . . A. baillonii

Fruiting material (except $A$. baillonii of which fruits are unknown)

1a. Exocarp smooth, capsules flattened, spindle-like . . . . . . A. banaensis

b. Exocarp slightly or heavily rugose, capsules obovoid or globose. . . . . . . 2

2a. Capsules obovoid, 4 by $3 \mathrm{~cm}$, exocarp slightly rugose ......... A. crassna

b. Capsules globose, 2 by $2 \mathrm{~cm}$, exocarp heavily rugose ......... A. rugosa

\section{Aquilaria rugosa L.C. Kiet \& Keßler, spec. nov. - Fig. 1}

\begin{abstract}
Arbuscula usque ad $10 \mathrm{~m}$ alta. Folia obovata vel obovata, $8-10(-12) \mathrm{cm}$ longa, 3.5-4.5 $\mathrm{cm}$ lata, chartacea vel subcoriacea, apice caudato-acuminata, caudis usque ad $1 \mathrm{~cm}$ longis, nervis $20-25$, ascendentis ad marginem incrassatum. Umbellae subsessiliae, pedicellis setosis. Hypanthium tubulare, infundibulare vel campanulatum, $4.5-6.5 \mathrm{~cm}$ longum, villosum, 10-costatum. Calyx 5 lobis, ovatis ad deltoideis, patentis vel reflexis, villosis tubo aequilongis. Appendices corollarum 10, ovatae vel semi-orbiculatae, ca. $1 \mathrm{~mm}$ longae, villosae. Stamina 10, 2-verticillata, glabra, antherae introrsae, ca. $1 \mathrm{~mm}$ longae. Ovaria $2.5-3.5 \mathrm{~mm}$ longa, in sectione transversali rectangularia, biloculares, ovulum 1 per loculum. Stigma irregulare lobata. Capsula bilocularis bivalves loculicide dehiscens globosa vel pyriformis, apice truncato vel depresso, basin constricto, exocarpio rugoso, stipite 2-3 mm longo, hypanthio persistenti. Valvae maturae 2, expansae. Semina 2, $7.5 \mathrm{~cm} \times$ $6.5 \mathrm{~mm}$, tomentosa, apice acuto, caruncula tortili in sicco. - Typus: Kiet 1936 (holo L), Vietnam, Kontum province, 500 m alt., in fruit, 17 July 2004.
\end{abstract}

Tree up to $10 \mathrm{~m}$ high, bole straight up to $3 \mathrm{~m}$, or shrub 4-5 m. Bark grey, rugose with a fine network of polygonal fissures; woody twigs with reddish brown bark, longitudinally fissured, glabrescent; young twigs densely pubescent. Foliar buds covered with silky hairs. Leaves ovate to obovate, $8-10(-12)$ by $3.5-4.5 \mathrm{~cm}$, chartaceous to subcoriaceous, dull, base attenuate or obtuse, rarely rounded, margin slightly recurved, white ciliate; apex shortly acute to acuminate, the acumen up to $1 \mathrm{~cm}$ long, both surfaces mostly glabrous, midrib sparsely appressed hairy beneath, depressed above, veins 20-25 pairs, subparallel, distinct beneath, obscure above, simple or sometimes forked, slightly curved and ascending towards the thickened marginal vein. Petiole 5-7 $\mathrm{mm}$ long, pubescent when young, canaliculated above. Inflorescences terminal on young twigs, or on short lateral branchlets, umbelliform, in 1-, 2- or many- (8-15-)flowered umbels, or sometimes branched with 2 or 3 umbels and each with $8-15$ flowers, more rarely a simple umbel; umbel with a short peduncle or subsessile, densely hairy, usually with a few small (caducous) bracts; pedicels $0.8-1 \mathrm{~cm}$, setose. Hypanthium (floral tube) whitish to yellowish, shortly tubular, funnel- or bell-shaped, 4.5-6.5 mm long, villose on both surfaces, distinctly 10 -ribbed outside; calyx lobes 5 , slightly ovate to deltoid, spreading or reflexed, villose, as long as the floral tube. Petaloid appendages 


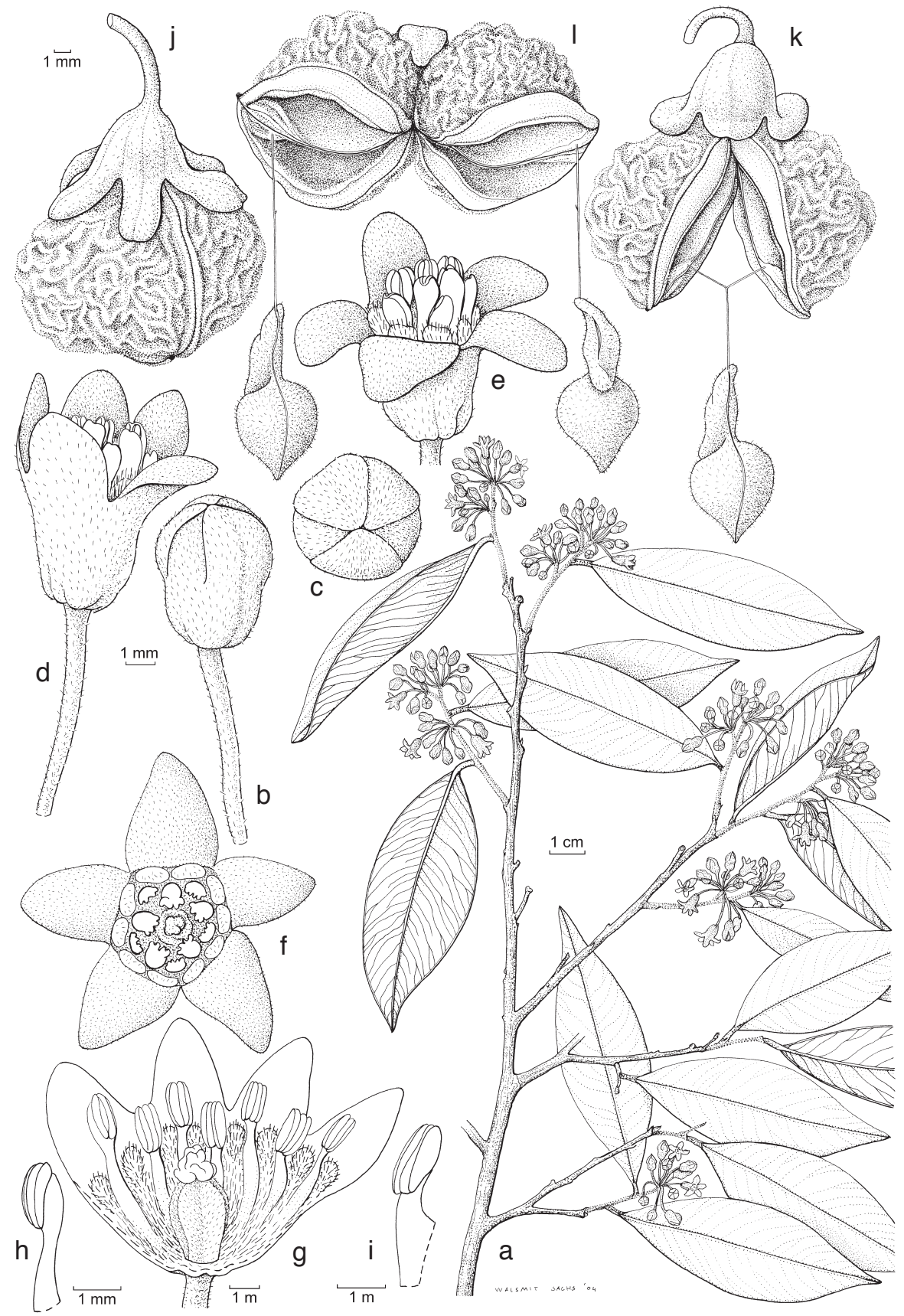

Fig. 1. Aquilaria rugosa L.C. Kiet \& Keßler. a. Habit (Heuveling van Beek 1); b. flower bud; c. flower bud from above; d. flower bud at the beginning of anthesis; e. open flower, lateral view; f. open flower from above; g. flower (longitudinal section); h, i. stamens; j. closed capsule (Kiet 1936); k. capsule at early state with dangling seed; 1 . fully open capsule at maturity. 
ovate or semi-orbicular, c. $1 \mathrm{~mm}$ long, densely villous, inserted slightly behind the stamens, free, about half-shorter than the stamens. Stamens 10, inserted in two whorls, slightly below the petaloid appendages, all with fleshy filaments, glabrous, the episepalous ones longer; anthers oblong, introrse, c. $1 \mathrm{~mm}$ long, glabrous. Pistil c. $2 \mathrm{~mm}$ long, hairy. Ovary rectangular in section, $2.5-3.5 \mathrm{~mm}$ long, villose, 2-celled; 1 ovule per cell, hanging near the top of the ovary; style obscure or absent; stigma irregularly lobed, light brown. Infructescences terminal, umbelliform, sessile or on 1-2 mm long peduncles bearing 5-8 fruits. Pedicels c. $10 \mathrm{~mm}$ long. Capsules globose or pyriform, ash grey when dry, 2 by $2 \mathrm{~cm}, 2$-celled, truncate to depressed at the apex, constricted at the base into a 2-3 mm long stipe, hypanthium (floral tube) persistent, campanulate, entire, c. $11 \mathrm{~mm}$ long, distinctly 10-ribbed outside, transverse section of capsule c. $2 \mathrm{~cm}$ across, marked by 4 lines, of which 2 prominent opposite ones belong to the suture; valves 2 , thick, angle of dehiscence to $180^{\circ}$ at the very maturity, mesocarp spongious when young; exocarp rugose (hence the name) outside at maturity or when dry, pericarp woody at maturity or when dry. Seeds 2, ovoid, dark-brown, 7.5 by 6.5 $\mathrm{mm}$, acute at the apex; caruncle-like appendage as long as the seed, twisted when dry; seed and appendage densely covered with brownish hairs.

Distribution - Vietnam, Kontum, known only from the type locality.

Ecology - Recently cultivated at 500 m elevation.

Phenology - Flowering in April; fruiting in July.

Conservation status - Aquilaria rugosa is recorded from two home gardens where it was first cultivated using wild material collected from forest in the Sa Thay district 5 years ago. As the type locality is near the logged areas and the agarwood collectors are jealous to appropriate the wild trees for their own exploitation, we can consider that the species in its original habitat is endangered, although it is now successfully domesticated and produces agarwood by artificial inducement. For the moment it is known from few locations not far from areas prone to intensive and illegal logging, to which it seems restricted. It is likely that further inventory work in the forested areas of Sa Thay district will uncover new locations.

Notes - Aquilaria rugosa is similar in general appearance of vegetative habit and structures to most of the Aquilaria species, but it differs from the others by shape, ornamentation pattern of the epicarp surface, and dehiscence of the fruit. Rugose sculptures on the exocarp surface are rare in Aquilaria. When going through literature and the herbarium collections in the Herbarium Bogoriense, the Herbarium of Singapore and the Nationaal Herbarium Nederland, Universiteit Leiden branch, for the EC-TRP project (see acknowledgement) we came across all the species so far described in the literature of this genus. Three species have ornamented exocarp surface: A. citrinaecarpa Hallier f. from the Philippines with small glandular-like dots; the Malesian species A. microcarpa Baill. with minute sinuous lines; only the Chinese species A. yunnanensis S.C. Huang has an exocarp surface similar to our A. rugosa, but the fruit shape is globoid and slightly compressed (vs globose-cordiform), with a convex apex (vs depressed apex), a dehiscence with 2 valves stretched at acute angle (vs 2 valves stretched at $180^{\circ}$ ), and the ovary is ovoid (vs shallow-longitudinally grooved).

The material used in this description consists of a specimen in flower collected in April 2003 by H. Heuveling van Beek and several specimens in fruit collected in July 
2004 by the first author. Flowering and fruiting were profuse during our inventory activities. The wounded wood produces agarwood under natural traumatism and artificial stimulation.

Specimens examined:

VIETNAM. Kontum province; Kiet 1936 (holotype L), 1940, 1941, Heuveling van Beek 1 (all L).

\section{ACKNOWLEDGEMENTS}

The work resulting in this publication was carried out in the context of the EC-TRP project on 'Sustainable use and conservation of agarwood in Vietnam' (2002-2005), and was financially supported by the Coordinator of the project, H. Heuveling van Beek.

The authors wish to acknowledge Prof. Dr. P. Baas, Director of the Nationaal Herbarium Nederland (NHN), Universiteit Leiden branch, for his keen interest, encouragement, and hospitality. Thanks also go to the staff members of the NHN for the facilities offered to our work and for their conviviality during our stay in Leiden. Dr. F. Adema kindly corrected an earlier draft of the manuscript. We are also most grateful to Dr. Ding Hou, the world-known specialist on Malesian Aquilaria who studied our specimens, provided us with detailed information, and dedicated his expertise to our identification. We are indebted also to Ms. A.V.M. Walsmit Sachs-Jansen for the line drawings who prepared the drawing on very short notice. Dr. B. Gravendeel is thanked for her contribution to the molecular analysis. Brian Gunn and Margaret Singadan are thanked for supplying material from Papua New Guinea.

\section{REFERENCES}

Domke, W. 1934. Untersuchungen über die systematische und geographische Gliederung der Thymelaeaceen. Biblioth. Bot. 27, Heft 111: 1-151.

Hô, P.H. 1992. Thymelaeaceae. Fl. Cambodge, Laos \& Vietnam 26: 38-52. Muséum National d'Histoire Naturelle, Paris.

Hou, Ding. 1960. Thymelaeaceae. Flora Malesiana 6: 1-59. Rijksherbarium, Leiden.

Lamarck, M.C. 1783. Encyclopédie Méthodique. Botanique 1. Paris.

Eurlings M.C.M. \& B. Gravendeel. In press. TrnL-trnF sequence data imply paraphyly of Aquilaria and Gyrinops (Thymelaeaceae) and provide new perspectives for agarwood identification. Pl. Syst. Evol.

White, T.J., T. Bruns, S. Lee \& J. Taylor. 1990. Amplification and direct sequencing of fungal ribosomal RNA genes for phylogenetics. In: M.A. Innis, D.H. Gelfand, J.J. Sninsky \& T.J. White (eds.), PCR Protocols: A guide to methods and applications: 315-322. Academic Press, San Diego, CA. 